\title{
ORDYNACJA ZAKONNA BONIFRATRÓW Z 1724 ROKU
}

Zakon Szpitalny św. Jana Bożego (1495-1550) ma dzisiaj bogatą dokumentację dla badań i pogłębiania zasadniczych i żywotnych cech szpitalniczego charyzmatu zakonodawcy.

W porządku chronologicznym i merytorycznym są to: listy św. Jana Bożego, biografia świętego, napisana przez Franciszka de Castro i opublikowana w $1585 \mathrm{r}$. Bardzo ważne i istotne są pierwsze konstytucje szpitala w Granadzie i trzy podstawowe bulle: Licet ex debito Piusa V (1 stycznia 1572 r.), Etsi pro debito Sykstusa V (1 października 1586 r.), Piorum Vinorum Pawła V (12 kwietnia 1608 r.).

Pierwszymi konstytucjami były:

1. Regla y Constituciones para el Hospital de Ioan de Dios, desta Ciudad de Granada ... 1585. (Reguła i Konstytucje dla Szpitala Jana Bożego, w tymże mieście Granadzie),

2. Constituciones hechas en el primer Capitulo General en Roma ano de 1587. (Konstytucje sporządzone na pierwszej Kapitule generalnej w Rzymie w ro$\mathrm{ku}$ 1587),

3. Constitutioni et ordini da osservarsi dagli Frati dell' Ordine di Giovanni di Dio ... 1585. (Konstytucje i polecenia do przestrzegania przez braci Zakonu Jana Bożego),

4. Constitutioni del devoto Giovanni di Dio di Italia, 1598. (Konstytucje pobożnego Jana Bożego, z Włoch),

5. Regla del Bienaventurado Padre San Augustin de la Orden de Juan de Dios, Madryt 1612. (Reguła Błogosławionego Ojca św. Augustyna z Zakonu Św. Jana Bożego) ${ }^{1}$.

Papież Paweł V brewem z 7 stycznia 1611 roku uznał synów duchowych św. Jana Bożego za zakonników, a 15 kwietnia 1617 roku zatwierdził ich konstytucję. Urban VIII w 1624 roku przyznał im prawa i przywileje zakonów żebrzących.

Szpitale - konwenty w różnych krajach tworzą oddzielne prowincje zakonne, zależne od generała zakonu i kapituły, mających siedzibę w Rzymie ${ }^{2}$.

$\mathrm{Na}$ ziemiach polskich bonifratrzy obecni są od 1609 roku (w Krakowie, potem w innych miejscach). Gdy ilość klasztorów zaczęła znacząco wzrastać (w

\footnotetext{
${ }^{1}$ Karta Tożsamości Zakonu Szpitalnego, Warszawa 2000, s. 150-151.

${ }^{2}$ S. R o s i a k, Bonifratrzy w Wilnie, Wilno 1928, s. 21-22.
} 
XVII wieku), powstała samodzielna prowincja, polsko-litewska (jedna z liczniejszych później w Zakonie), pod wezwaniem Najświętszej Maryi Panny.

Zarząd nad nią sprawowali: prowincjal i dwaj deputaci, wybierani na kapitułach generalnych i średnich. Na czele prowincji stał prowincjał, wybierany na kapitule, względnie wikariusz, wyznaczany przez wyższe władze duchowne ${ }^{3}$.

Polska, w pierwszym okresie rozwoju zakonu, tworzyła wikariat generalny pod zwierzchnictwem wikariusza. Pierwszym był o. Franciszek Barbavara, z pochodzenia Włoch (w latach 1609-1627, z przerwą w latach 1616-1619).

Pierwszym prowincjałem polskim, z wyboru na kapitule rzymskiej, w kwietniu 1633 roku, został o. Spiritus Scotinus. Był na tym stanowisku, z tytułem prowincjała Polski i Wielkiego Księstwa Litewskiego, do kapituły rzymskiej w 1645 roku ${ }^{4}$.

Kraków stał się miejscem domu macierzystego polskich bonifratrów, był najpierw siedzibą wikarych generalnych, a potem prowincjałów. Stąd wychodziły wszystkie dyrektywy, przepisy prawne; roztaczały się rządy na całą prowincję. Tutaj też, zapewne, dotarły z Rzymu pierwsze reguły i konstytucje zakonne.

Najstarszymi (drukowanymi), zachowanymi w konwenckim archiwum, konstytucjami sa: Konstytucje po 1683 roku oraz Konstytucje z 1728 roku $^{5}$.

Niezmiemie cennym dokumentem (rękopiśmiennym) jest: Ordynacja dla polsko-litewskiej prowincji bonifratrów, z dnia 3 sierpnia 1724 roku, skierowana do przełożonych klasztorów przez Franciszka Neumana (w tym samym roku, nieco później, wybranego na prowincjała) ${ }^{6}$.

W artykule niniejszym przedstawia się go w całości, by widzieć, jak w przeszłości przełożeni zakonni, poprzez formułowane zalecenia, starali się doskonalić i organizować życie zakonne.

W 1724 roku o. Franciszek Neuman był prezbiterem i wizytatorem prowincjalnym Zakonu św. Jana Bożego w Królestwie Polskim i Wielkim Księstwie Litewskim, przeorem gdańskiego klasztoru i szpitala pw. św. Jana Chrzciciela ${ }^{7}$.

\footnotetext{
${ }^{3}$ Tamże, s. 23; H. Łań - M i row s k a, Bonifratrzy w Polsce, Rzym 1984, s. 17.

${ }^{4} \mathrm{~S}$. R o s i a k, Bonifratrzy w Wilnie, dz. cyt., s. 22.

${ }^{5}$ G. Z y g m un t, Bonifratrzy w Krakowie, Warszawa 1982 (rozprawa doktorska), s. 68.
} Konstytucja z 1728 roku to: Swiatło dróg niebieskich Wielkiego w Kościele Bożym Luminarza Augusta Świętego. Reguła y Konstytucya S. Iana Bożego, dla Braci od Miłosierdzia. W splendorze Godnych Imion Przewielebnego w Bogu Oyca Franciszka Neuman Prowincyala, y Wielebnych Oyców Przeorów Polskiey y Litewskiey Prowincyi tegoż Zakonu. Publicznemu na widolk światu wystawiona. Przez W.O.R.B.K.W.G.P. Roku Pańskego 1728. Archiwum Donifratrów Krakowie.

${ }^{6}$ S. R o s i a k, Bonifratrzy w Wilnie, dz. cyt., s. 27. W 1724 roku, na kapitule prowincjalnej w Warszawie, prowincjałem wybrano o. Franciszka Neuman. Był nim do 1729 roku. W 1728 roku wizytował krakowski konwent. W „Księgach 1724-1781” zachował się jego podpis, wikariusza generalnego i prowincjała. Archiwum Bonifratrów, Kraków. Ponad 20 lat wcześniej, w 1707 roku, o. F. Neuman był czlonkiem konwentu krakowskiego. W kronice z tego okresu zapisano: W 1707 roku, wyjeżdżając na kapitułę generalną do Rzymu, przeor krakowski, Bernard Mackiewicz, wyznaczył na okres swojej nieobecności, zastępcę - F. Neumana. Jemu zalecil dbałość o obserwę zakonna, porządek w konwencie, troskę o chorych, o klauzurę. Archiwum Bonifratrów w Krakowie, Kronika klasztoru, 1707 r.

${ }^{7}$ F. Neuman, Ordinatie Roku 1724, Archiwum Bonifratrów w Krakowie. 
Brat Franciszek Neuman aktualny prezbiter $i$ wizytator prowincjalny w Królestwie Polskim oraz Wielkim Księstwie Litewskim, jak również przeor należacych do Zakonu św. Jana Bożego gdańskiego klasztoru i szpitala pod wezwaniem św. Jana Chrzciciela.

Do regularney zakonnego życia obserwantij, dla którey utrzymania z powinności naszey jako najpilniey przestrzegać zawsze wszystkimi siłami usiłujemy y to najpotrzebniejsze wprzod naybardziej być sądzimy, aby Chwała Boska pomnożenie swoie zawsze bierała, przeto na początku rządu naszego na zachowanie dobra zakonnego, na większą Cześć Boga ordinatie niżey opisane ku dobremu rządu stosuiące się, aby od wo. Przeorów, superiorów y wikariów wcale zachowane y do skutku wiernie przywiedzione były, stanowimy.

Ordinatie roku 1724 dnia 3. Augusta:

Należycie powinna Reverentia Nayświętszemu na ołtarzu

Sakramentowi zawsze ma być oddana. Y chcemy, aby zawsze tak we dnie, iako i w nocy lampa wkościele świeciła, gdyż przez małą partią łoiu, oleiu albo oliwy na czesc Wcielonemu Słowı ofiarowaną konwent do ubóstwa, że się pali, nie przyidzie, owszem y z chorymi z tlusta/tluszcza??? Niebieskiego nasyceni y sami będziemy.

Renovatia Nayświętszego Sakramentu należytym porządkiem zawsze

ma być y na tablicy w Zakrystij sporządzoney na to napisana.

Na godziny albo officium Nayśw. Panny według chwalebnego

zwyczayu naszego Zakonu i do choru, tak rano iako y od wieczora aby wszyscy bywali, chyba który słusznie zatrudniony albo z wyraźnym pozwoleniem (które barzo trudno niech się pozwala) nie mógłby. Także kapłani Zakonu naszego, którzykolwiek y iacykolwiek by byli poobudzeniu aby wraz wstali y za zadzwonieniem $z$ bracia przychodzili do drzwi wo. Przeora, gdzie po trzykrotnie zakołatawszy mówiąc Laudetur Jesus Benedicte Pater (wyniydzie ieżeli będzie przytomny wo. Przeor z celi) a kapłan zacznie który z psalmów y póydą aż do chóru, gdzie skończywszy psalm hebdomadarz, albo któremu wo. Przeor każe, zacznie exercitium, powoli nabożnie odprawiać y rzetelnie, a zaś kapłan poydzie sobie na mieysce w kościele. Godziny, ieśli ich nie odmówił, kapłańskie odmówić. A gdy będą godziny za umarłych, powinien będzie one z bracią y kapłan odmówić. A ten zwyczay zachować maią choćby bez bytności wo. Przeora y za wikarego. Po odprawieniu godzin kapłan poydzie $z$ bracia, mówiąc psalm który do infirmarij y tam będzie ksiądz usługiwał ubogim, dając z siebie przykład pokory braciey innym. Ten porządek zachować się ma y od wieczora. Y dla niebytności braciey dokonywać godziny: gdyż dość czasu zbywa na nieszpór swoy. A żaden niech nie wychodzi, ani wyzwany bywa brat $z$ chóru, chyba dla wielkiey przyczyny y potrzeby.

Kapłan nie będzie mógł według swego upodobania kazać dzwonić na

msza, ale wo. Przeor naznaczy czas według zwyczaiu, inny lecie, inny zimie. Pierwszy raz zadzwoniwszy nieco przestanie, drugi raz gdy zadzwonią iuz kapłan będzie ubrany.

Obligacye mszy każdego konwentu każdy y którykolwiek kapłan kogo.

odprawuje, wpisze w xięgę zakrystiańska, z wyrażeniem dnia, miesiąca y za

Że niektórzy oo. Kapłani Zakonu naszego często wychodzą do innych 
kościołów, bardziey dla wziątku niż dla nabożeństwa. W tym oo. Przeorowie niech przestrzegają. Item «ponado» aby wszyscy zakonnicy nasi (iakoż wszyscy powinni) co dzień na mszach świętych bywali i pilnie, nabożnie ze wszelką świętobliwością mszy św. słuchali. Dla czego upominamy Brata Zakrystiana, aby pilnie notował $w$ xiędze.

Gdy chorzy przyimuią się, aby im zaraz nogi były umywane, a potym

każdego dnia w sobotę, aby im katechizm był czytany, lubo inna iaka nauka duchowna, co wszystko powinność będzie kapłana na ów czas tam zostaiącego, lub y przy braciey przytomney.

Każdy kapłan Zakonu naszego ma się postarać, aby miał approbatią do

słuchania spowiedzi, choćby y zakonników i życzylibyśmy aby ieszcze mogli mieć y a casibus reservatis «odnośnie grzechów zastrzeżonych, tj. takich z których może rozgrzeszyć papież lub biskup», gdyż ta potrzebna do infirmarij naszych. Wolno iednak wo. Przeorowi naznaczyć spowiednika dla Braci zakonników. A na wizytach każdy kapłan ma pokazać od diecezyi swoiey namiestnika approbatia, y zalecamy, aby kazistów czytali.

Żaden z naszych Kapłanów niech się nie waży słowy uszczypliwymi

iako to laika, tako y Braci łaiać y wo. Przeor za to niech ich skarze.

Żadnemu z Kapłanów naszych (chyba w nagłey potrzebie) niech nie

będzie poruczony rząd konwentu, chyba który będzie przykładny, nabożny y w miłości braterskiey nie podejrzany, aby Bracia oppressyi nie mieli. A uchoway Boże, żeby który miał potrącić, nie mówię, uderzyć Brata - zaraz w więzienie wsadzić, o chlebie y wodzie trzymać y dać nam znać przyazuiemy oo. PP.

Żaden $z$ naszych kapłanów y braci niech się nie waży stronić od stołu

społecznego y nie starali się oo. Przeorowie, iako i kapłani w porcye osobne do celi nosić, chyba w chorobie.

Przykazuiemy, aby chorzy przyimowani byli $z$ wszelką miłością y

poszukani na ulicach, y niesieni na wzór oyca naszego św. Jana Bożego. Infirmaria aby zawsze czysto i chędogo była y wszelkie potrzeby prowidowane «zapewniane» chorym. A wo. Przeorowie aby postarali się y zmówili kontraktem cyrulików, kiedy y wiele razy chorych nawiedzić.

Żadnego chorego nie kłaść na łóżko, aż wprzód dobrze wywiedzieć

się, co za choroba y ieśli iest nadzieia iaka uleczenia, alias «w przeciwnym razie» zaraz go wyprawić. Infirmarz przestrzeże, aby chory nagotował się do Spowiedzi Św. i Komunij, ieśli bardzo słaby. Do cyrulika będzie należało słabych y chorych iakiemi pokarmy pokarmować y onych wszelkiemi lekarstwy ratować. Chory aby też nie wymyślał y nie napierał się portij sobie, ale iako ordinariynie.

Wielebni Ojcowie P̂rzeorowie niech boiaźn Boskį maia, co kazą

jałmużnę zbierać na chorych, a ich gdzie indziey y nie masz y w szpitalach drudzy y nie lubią. Lubo prowizye i fundatie pobożne na nich są.

Bracia niech konwersatij nie maią i konfidentią nie wdawaią się z

chorymi, ale tylko swoiej powinności y usługi przestrzegać.

Nowicyuszowie niech będą przyuczeni do pobożnych prac szpitalów y

innych dychownych ćwiczeń (iako jest opisane w Nowicyuszów Wychowaniu) y niech to wiedzą oo. magistrowie nowicyuszów, że na wizycie Bracia nowicyuszowie przy obecności swego magistra będą exzaminowani y pytani, czego się 
kto nauczył, a tak poznany będzie ich pożytek z nauki ich magistra. A żaden nowicyusz, uchoway Boże, niech nie będzie do miasta lub po jałmużnę wysyłany, iednak dla wielkiey y słuszney potrzeby $z$ dobrym y przykładem profesem może poyść y profes zawsze mu przykład $z$ siebie dobry ma dać.

Każdego miesiąca niech będzie Congregatia y regestra pisane

wyraźnie, rzetelnie w liniach wpodłuz. A Braciom starsi przestrzegać będa ieżeli iakiey omylki albo mankamentu nie masz w regestrach, które dopiero potym podpisza y za prawdziwe uznaya. A niech te regestra na zgromadzeniach czytane będą głośno y każdemu bratu wolno widzieć one będzie, rewidować y zkalkulować. Brat zaś szafarz swoie regestra, precept y expens <dochody i wydatki $>$ będzie na wszystkich zgromadzeniach prezentowal, yeżeli się zgadzayą z kapitalnemi y one zachowa wyraźnie spisane do wizyty naszey.

Gdzie folwarki są albo też y z kwesty wymłot zboża y cokolwiek się

przywozi, niech także będzie regestr u o. Przeora, a drugi u brata gospodarza, co y iak wiele posyła do klasztoru.

Żaden z naszych kapłanów niech się nie waży mieć do posług sobie za

serwitora braci zakonników. Chyba gdyby był magistrem nowicyuszów, tak iednak, aby się nie tak grubo obchodził, żeby był calefactorem <palaczem>, drwa rąbał, w piecu palał, iako iuż w tym doświadczony. Co wszystko wo. Przeor ma przestrzegać.

Kwestarze w drodze aby jak najskromniej obchodzili się. Oicowie

Przeorowie niech napominaja, (aby) i w dni święte, osobliwie w niedziele, w drodze będąc spowiadali się y komunikowali, y świadectwo lub na piśmie o tym od spowiednika przyjechawszy do konwentu przeorowi dali.

Także chcemy, aby w każdym konwencie była księga iedna

kwestarska exstraodinarijna. Cokolwiek z kolektury przywozi się, aby to było wpisane w przytomności dwóch albo trzech Braci y wo. Przeor skonotować postara się.

Bracia występni, gorszący z piiaństwa niech surowo będą karani o

chlebie y wodzie y pokuty tyloz przyczynić, ile piiaństwa.

Niech Wielebni Oycowie Przeorowie to oddalaia y żeby żaden

zakonnik po celach nie chował psów w konwencie, ani używał oręża, strzelb, szpad etc. Niech to Oyciec Przeor odbierze, dość zakonnikowi zbroi duchownei: xiążaka, pacierze et.

$\mathrm{Y}$ to niechwalebne y chcemy, aby Wielebni Oicowie Przeorowie

chowaiąc serwitorów świeckich do posług, nie mieli większey poufałości y powierzenia niźli do Braci, skąd y poswary bywaią i zakonne sekreta wyiawiaią się. I też przykazuiemy Wielebnym Oicom Przeorom, aby każdemu, czego trzeba dodawano było. Ponieważ iawna nam iest niektórych braci uzurpacia jałmużn kradzieyskim sposobem y powiadaja, że nam należytych potrzeb Oyciec Przeor nie daie. Aby taki zły uczynek nie powstał przykazuiemy.

Zakonnik, któryby Brat od rodziców swoich lub krewnych iakie

pieniądze dane miał, chcemy, aby to $z$ wiadomościa wo. Przeora było i wo. Prowincyała, chyba żeby to miał do konwentu aplikować y oddać może. A ieżeli by nie chciał, $z$ wiadomością wo. Prowinyała może mieć, jednak żeby nadmiernie nie przemarnował, ale na potrzeby swe zakonne obrócil y innych żadnych rzeczy za konwentem chować nie godzić się będzie. 
Każdy zakonnik niech umie na pytanie odpowiedzieć, którego roku

Błogosławiony Jan Boży, patriarcha nasz, urodził się, gdzie, w którym kraiu, co za cuda, kiedy Zakon postanowił y iak długo trwa etc. To wszystko niech da informatią braciey kapłan. Bracia zaś niech wszędzie z sobą i wdrodze maią żywot, regułę y constitutią św. Jana Bożego.

A że wielu z naszych zakonników przyzwyczaili się listy fomentalne

«wichrzycielskie» przeciw swoim przełoźonym pisać, napominamy y upominamy, aby tego na potym poprzestali y ieśliby mial co który przeciw komu lub przełożonemu swemu, niech to na kongregatiach przekładaia, tam sprawiedliwości doydą. A że y tacy nayduią się, którzy zwykli listy przeymować od przełożonego do przełożonego pisane, ninieyszemy ordinatiami przestrzegamy i zakazuiemy tego, alias «w przeciwnym razie» doświadczony będzie skarany, y też którzy pieczęć sobie priwatną zmyślaia, niech się tego nie ważą. A ieśli w wielkiej iakiej rzeczy potrzeba będzie, to niech będzie z wiadomością wo. Przeora konwentska pieczęcią pieczętować.

I ten zwyczay znosimy, aby bracia nasi dla traktamentów iakich «tj. w

celach leczniczych» nie posyłali sobie po trunki iakie, miody, piwa etc., w czym wo. Przeor niech przestrzega.

Aerarium «skarbiec» niech będzie opatrzone y trzy klucze do niego.

Dwa niech będzie u Braci, a trzeci u wo. Przeora, aby wiedział zawsze, co w nim iest.

Żaden z Przeorów niech się nie waży przed czasem prowizyi odbierać

bez wiadomości Braciey dwóch albo trzech, a daleko bardziej sumy kapitalne odbierać albo expendować «wydawać», choćby w naywiększej potrzebie. Też domów, placów, dóbr ruchomych y innych bez wyraźney licentij wo. Generała nie będą mogli alienować «przekazać na własność osobom trzecim», arendować «oddawac $w$ dzierzawę», przedać, alias «w przeciwnym razie» niech się iuż w kilątwę wpadly zna.

Także żaden przeor niech się nie waży srebra klasztome, kościelne przedać albo tabliczki na iakie naczynie, choćby do kościoła służące, kazać przerobić, póki pierwey to srebro na wizycie nie będzie widziane y z rady naszei do chwały Boskiey inaczey dysponowane. Ani też maią pierwey o iakie wyśmienitości do kościoła starać się, póki pierwey porządnie infirmaria nie będzie prowidowana $<$ zaopatrzona $>$.

Aby Bracia nasi umieli krwie puszczania, plastry przykładania etc., iako jest w Konstyt.

Gdy Bracia z obiedientią dokąd ida, oo. Przeorowie powinni chędogo

wyprawic y wysłac, a nie obdarto. O czym wszystikim na wizytach scisie to będzie pytano, y przeto idącemu wypisze, z czy idzie, aby supspicyi «podejrzenia» nie było, nie rozprzedał y postą «pocztą» pośle, albo sam zapieczętowane maiąc poniesie.

Nie ma się godzić Braciey naszey nosić suknie, iako to żupany y inne

na kształt świeckich zrobione koloru świetnego iakiego, gdyż często y pod falendronem «rodzaj grubego sukna» może się wydać przez ulicę idącemu, ale tylko szare albo czarne. 
A że niektórzy superiorowie lub xięża piiaństwem lub rankorem

«niechęcią) dawnym uwiedzieni z przeszłych okazyi, Bracią pod sobą będących pieścia, kiiem i aż do zekrwawienia bić nauczyli się, my temu zapobiegaiąc ordinuiemy, niech tak będzie postapiono, iako jest napisane w Konstyt. rozdział 3, do dalszey naszey decizyi.

Dla zachowania zakonney klauzury barziey który bykolwiek w nocy

bez licentij wyszedł z klasztoru, w tęż karę popadać ma co ślub czystości złamie, jako jest numer 7, y aby klasztory nasze czasu zwykłego były zamykane chcemy.

Przeciw posłuszeństwu występny niech ciężko karany będzie, iaj iest w Konstyt. numer 27.

Aby wszyscy Bracia na kongregatiach swoje rzeczy prezentowali, y ieśli kto czego będzie potrzebował, aby im dano. Także niech każdego miesiąca wedlug Konstyt. wo. Przeor dwóch albo iednego wziąwszy Braci wizytnie cele Braciey.

Te są nasze ordynatie, które chcemy y przekazuiemy, aby od wszystkich wiemie y skutecznie zachowane były y serio przykazuiemy Wielebnym Oicom Przeorom pod karą nam zachowana, aby ie każdego miesiąca na kongregatiach czytano, aby potym na wizytach nie wymówił się który nieświadomością. 1724

Brat Franciszek Neuman prowincjalny superior miejsce na pieczęć Brat Wincenty Monar sekretarz 


\section{Regulations of the Order of Saint John of God, from 1724 Summary}

The article is a publication of the document presenting the regulations of the Order of St. John of God in the Lithuanian Province, written in 1724. These regulations - "to be helpful while rightly controlling" and "to preserve the order's well being", "set up to honour the God"were handed down to the superiors of all the convents.

Similar to constitutions, these regulations were to perfect and to organize the life in an Order. Engrossed in 39 points, these injunctions were for all members of the Order of St. John of God in the province: a superior, priests, friars of all professions e.g. nurses, hosts, collectors of funds, dispensers etc.

The regulations were also to give advice for those being totally devoted to God, how to properly care for the vocation while working with the needy and with the poor and sick, how to unite with God and to strive after the sanctity of life with the help of the Eucharist, prayer, liturgy, adoration of the Holy Sacrament, religious readings, permanent contact with the convent's constitution and with the descriptions of the life of St. John of God.

One can also find here advice how to develop love, trust and goodwill, obedience and responsibility when living in a fraternal community. At the end of this document we read following: "these regulations (...) we want them to be truly observed by everyone (...) and to be read every month at congregations". 